\title{
Production of Ulvan Oligosaccharides with Antioxidant and Angiotensin-Converting Enzyme-Inhibitory Activities by Microbial Enzymatic Hydrolysis
}

\author{
Yueh-Hao Ronny Hung ${ }^{1}$, Guan-Wen Chen ${ }^{1}$, Chorng-Liang Pan ${ }^{1, *}$ and Hong-Ting Victor Lin $1,2, *$ (D) \\ 1 Department of Food Science, National Taiwan Ocean University, No. 2, Pei-Ning Road, Keelung 202, Taiwan; \\ ronnybig28@gmail.com (Y.-H.R.H.); chengw@email.ntou.edu.tw (G.-W.C.) \\ 2 Center of Excellence for the Oceans, National Taiwan Ocean University, No. 2, Pei-Ning Road, \\ Keelung 202, Taiwan \\ * Correspondence: b0037@mail.ntou.edu.tw (C.-L.P.); HL358@ntou.edu.tw (H.-T.V.L.); \\ Tel.: +886-2-24622192 (ext. 5116 \& 5121) (C.-L.P. \& H.-T.V.L.); Fax: +886-2-24634203 (C.-L.P. \& H.-T.V.L.)
}

check for

updates

Citation: Hung, Y.-H.R.; Chen, G.-W.; Pan, C.-L.; Lin, H.-T.V. Production of Ulvan Oligosaccharides with

Antioxidant and AngiotensinConverting Enzyme-Inhibitory Activities by Microbial Enzymatic Hydrolysis. Fermentation 2021, 7, 160. https://doi.org/10.3390/

fermentation7030160

Academic Editor: Yi-huang Hsueh

Received: 5 August 2021

Accepted: 19 August 2021

Published: 21 August 2021

Publisher's Note: MDPI stays neutral with regard to jurisdictional claims in published maps and institutional affiliations.

Copyright: (c) 2021 by the authors. Licensee MDPI, Basel, Switzerland. This article is an open access article distributed under the terms and conditions of the Creative Commons Attribution (CC BY) license (https:// creativecommons.org/licenses/by/ $4.0 /)$.
Abstract: Seaweed oligosaccharides have attracted attention in food, agricultural, and medical applications recently. Compared to red and brown seaweeds, fewer studies have focused on the biological activity of green seaweed's oligosaccharides. This study aimed to produce bioactive ulvan oligosaccharides via enzymatic hydrolysis from green seaweed Ulva lactuca. Ulvan, a water-soluble polysaccharide, was obtained by hot water extraction. Two isolated marine bacteria, Pseudomonas vesicularis MA103 and Aeromonas salmonicida MAEF108, were used to produce multiple hydrolases, such as ulvanolytic enzymes, amylase, cellulase, and xylanase, to degrade the ulvan extract. An ultrafiltration system was used to separate the enzymatic hydrolysate to acquire the ulvan oligosaccharides (UOS). The characteristics of the ulvan extract and the UOS were determined by yield, reducing sugar, uronic acid, sulfate group, and total phenols. The FT-IR spectrum indicated that the ulvan extract and the UOS presented the bands associated with $\mathrm{O}-\mathrm{H}, \mathrm{C}=\mathrm{O}, \mathrm{C}-\mathrm{O}$, and $\mathrm{S}=\mathrm{O}$ stretching. Angiotensin I converting enzyme (ACE) inhibition and antioxidant activities in vitro were evaluated in the ulvan extract and the UOS. These results provide a practical approach to producing bioactive UOS by microbial enzymatic hydrolysis that can benefit the development of seaweed-based products at the industrial scale.

Keywords: ulvan; marine bacteria; enzymatic hydrolysis; ulvan oligosaccharides; antioxidant activity; ACE inhibition

\section{Introduction}

Seaweed is nutritious biomass and is widely distributed in the sea's intertidal zone. It can be categorized into three major groups, Rhodophyta (red), Phaeophyta (brown), and Chlorophyta (green) algae. Ulva sp. is a common green seaweed occurring in the intertidal zone and eutrophicated coastal area [1]. Both farming and harvesting are being applied to collect Ulva. For example, over 1 thousand tonnes of fresh weight Ulva sp. were cultivated on South African abalone farms in 2007 [2]. Approximate 2.01 thousand tonnes of Ulva sp. were reaped for aquaculture feeds in 2013 [3], and approximately 32.9 thousand tonnes of green seaweeds (including 2.37 thousand tonnes of Ulva) were produced (farmed and wild) in 2019 [4]. In dried seaweed, carbohydrate is the most abundant constituent, generally followed by ash, protein, and then lipid [5]. Ulva sp. contains high amounts of polysaccharides (15-65\%), and it also has 4-44\% protein, $0.3-1.6 \%$ lipid, and 11-55\% ash in the dried biomass [6]. Four common cell wall polysaccharides in Ulva sp. are ulvan, cellulose, alkali-soluble linear xyloglucan, and glucuronan. Ulvan, the major cell wall polysaccharide, showed $8-29 \%$ in the dried biomass $[7,8]$.

Ulvan is composed of a repeating linkage of disaccharides, for example, ulvanobiuronic acids as the primary one followed by ulvanobioses $[9,10]$. The ulvanobiuronic 
acids are designed as type A: ulvanobiuronic acid 3-sulfate $\left(\mathrm{A}_{3 \mathrm{~s}}\right)$, which is glucuronic acid linked to O-3-sulfate rhamnose, and type B: ulvanobiuronic acid 3-sulfate $\left(\mathrm{B}_{3 \mathrm{~s}}\right)$, which is iduronic acid linked to O-3-sulfate rhamnose [11]. On the other hand, the ulvanobioses are designed as ulvanobioses $\mathrm{U}_{3 \mathrm{~S}}$, which is a xylose linked to O-3-sulfate rhamnose and

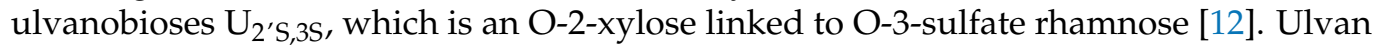
has several biological activities, such as antioxidant, antiviral, anticoagulant, antihyperlipidemic, immunomodulatory activities, and anti-proliferative towards cancer cells [6,13,14]. The structure and composition of ulvan plays an essential role in its biological functionality. For example, a low molecular weight fraction of ulvans has a stronger antioxidant activity [15], immunomodulatory activity [16,17], and antihyperlipidemic effect [18]. In addition to polysaccharides, marine oligosaccharides are potential resources for food, cosmetic, medical fields. For polysaccharide degradation and oligosaccharide production, chemical and physical treatments are common methods applied in seaweeds [19]. Chemical hydrolysis has advantages of low processing cost and simplicity in operation, such as acid and alkali hydrolysis [20]. However, using acid or base to hydrolyze the seaweed polysaccharides, it is possible to acquire by-products (e.g., 5-HMF or furfural) and non-specific oligomers at the end of the process [21]. Compared to those processes, enzyme treatment has mild conditions to degrade polysaccharides. To further boost the yield of specific and bioactive products from seaweeds, enzymatic hydrolysis is a potential treatment in which enzymes can target the complex structure of seaweeds specifically $[19,22]$.

To the best our knowledge, there are few studies on bioactivities of ulvan oligosaccharides than red and brown seaweed oligosaccharides. There has been no previous report to use the ulvan-degrading enzymes derived from Pseudomonas vesicularis and Aeromonas salmonicida for ulvan oligosaccharides production. This study aimed to produce bioactive ulvan oligosaccharides from Ulva lactuca by exploiting the multiple enzymes from isolated marine bacteria cultures. In addition, chemical characteristics, molecular weight distribution, and functional groups of ulvan extract and mixed ulvan oligosaccharides were determined. Furthermore, we showed the antioxidant activities and inhibitory ability of angiotensin I converting enzyme (ACE) of the ulvan oligosaccharides. We provide an economic, promising process for producing bioactive ingredients from seaweeds at an industrial scale.

\section{Materials and Methods}

\subsection{Seaweed}

Ulva lactuca was cultivated and bought from Ho-Ping island, Keelung, Taiwan. The biomass samples were washed with tap water and then dried with air at $30{ }^{\circ} \mathrm{C}$ for $24 \mathrm{~h}$ before being ground into powder ( 40 mesh). The seaweed powder was stored at $-20^{\circ} \mathrm{C}$.

\subsection{Marine Bacteria}

Two marine bacteria, Pseudomonas (P.) vesicularis MA103 and Aeromonas (A.) salmonicida MAEF108, were isolated from the seawater from the coast in Keelung, Taiwan as indicated in $\mathrm{Wu}$ et al. [23]. Previous studies have shown that these two marine bacteria, MA103 and MAEF108, could produce different hydrolases to degrade seaweed polysaccharides, such as agar, carrageenan, and fucoidan (data not shown). Thus, both strains were investigated for the ulvan degradation in this work.

\subsection{Production of Ulvan Extract}

The ulvan extract was made from Ulva lactuca based on the procedure built by Alves et al. [24] with slight modifications. The Ulva powder $(21.0 \mathrm{~g})$ was suspended in distilled water $(700 \mathrm{~mL})$ and extracted at $110{ }^{\circ} \mathrm{C}$ for $75 \mathrm{~min}$. The extract was centrifuged at $10,000 \times \mathrm{g}$ at $15^{\circ} \mathrm{C}$ for $20 \mathrm{~min}$ to remove the residues, and the supernatant was filtered through a filter paper ( $0.5 \mu \mathrm{m}$ pore size) $(4 \mathrm{~mm}$; Pall Corp., Ann Arbor, NY, USA). Furthermore, the filtrate was concentrated $(2 \times)$ by ultrafiltration using a $30 \mathrm{kDa}$ polyethersulfone (PES) membrane for recovering the high molecular weight fraction of polysaccharides (Vi- 
vaflow 50, Vivascience, Hannover, Germany). The retentate was diafiltered with deionized water during the ultrafiltration and crude ulvan concentration was obtained. To purify the polysaccharides, the concentrated fraction was mixed with 95\% ethanol in a ratio of 1:6 at $4{ }^{\circ} \mathrm{C}$ for $12 \mathrm{~h}$, and the precipitate was collected and frozen at $-80{ }^{\circ} \mathrm{C}$. Finally, the purified ulvan extract was acquired after lyophilization.

\subsection{Collecting Ulvan-Degrading Enzymes from Marine Bacteria}

The ulvan extract $(0.15 \mathrm{~g})$ was added into $50 \mathrm{~mL}$ of modified marine medium (marine broth 2216:40.3 g/L; tris (hydroxymethyl) aminomethane: $1.0 \mathrm{~g} / \mathrm{L}$; sodium chloride: $6.0 \mathrm{~g} / \mathrm{L}$; sodium nitrate: $1.0 \mathrm{~g} / \mathrm{L}$; monopotassium phosphate: $0.1 \mathrm{~g} / \mathrm{L}$ ) and sterilized $\left(121^{\circ} \mathrm{C} / 20 \mathrm{~min}\right) .2 \%(v / v)\left(1.0 \times 10^{6} \mathrm{CFU} / \mathrm{mL}\right)$ of $P$. vesicularis MA103 and $A$. salmonicida MAEF108 was inoculated individually in the medium; the culture was incubated at $26{ }^{\circ} \mathrm{C}$ at $100 \mathrm{rpm}$ for 1-4 days to produce multiple hydrolases. To prepare the crude enzyme solution from MA103 or MAEF108, the culture broth was centrifuged $(12,000 \times g)$ at $4{ }^{\circ} \mathrm{C}$ for $30 \mathrm{~min}$ and filtered $(0.22 \mu \mathrm{m})$ (33 mm; Millex-GS, Millipore, Bedford, USA).

\subsection{Enzymes Activity Assays}

Measurements for the activities of amylase, xylanase, cellulase, and ulvanolytic enzyme were accomplished accordingly to previous reports with slight modifications $[11,25,26]$. The substrate solution for ulvanolytic enzyme was $6 \mathrm{~g} / \mathrm{L}$ and the ulvan extract in $100 \mathrm{mM}$ Tris- $\mathrm{HCl}$ ( $\mathrm{pH}$ 9.0) with $25 \mathrm{mM} \mathrm{CaCl}_{2}$ (Panreac). Substrate solutions for amylase, xylanase, and cellulase were $0.4 \mathrm{~g}$ soluble starch, $0.4 \mathrm{~g}$ birchwood xylan, and $1.0 \mathrm{~g}$ carboxymethyl cellulose sodium in $10 \mathrm{mM}$ Tris- $\mathrm{HCl}$ ( $\mathrm{pH} 7.0)$, respectively. In the tests, $0.05 \mathrm{~mL}$ crude enzymes solution of MA103 or MAEF108 was added into $0.45 \mathrm{~mL}$ substrate solution to proceed the hydrolysis. Reactions of amylase and ulvan lyase were conducted at $40{ }^{\circ} \mathrm{C}$ for 40 and $30 \mathrm{~min}$, respectively. Reactions of cellulase and xylanase were conducted at $37^{\circ} \mathrm{C}$ for $10 \mathrm{~min}$. After hydrolysis, $0.5 \mathrm{~mL}$ of DNS reagent $(1 \mathrm{~g} / \mathrm{L} 3,5$-dinitrosalicylic acid (Panreac), $300 \mathrm{~g} / \mathrm{L}$ potassium sodium tartrate (Panreac), and $16 \mathrm{~g} / \mathrm{L}$ sodium hydroxide (Panreac)) was added, mixing thoroughly, and the mixture was boiled for $10 \mathrm{~min}$ to end the enzyme reaction. Finally, $1 \mathrm{~mL}$ of deionized water was added to the mixture. The amount of reducing ends was monitored by measuring the absorbance at $546 \mathrm{~nm}$ [27]. Dglucose, D-xylose, D-rhamnose were used to make standard curves for evaluating enzymes hydrolysis. One unit (U) of enzyme activity corresponds to the formation of $1 \mu \mathrm{mol}$ of monosaccharides/min [28].

\subsection{Production of Mixed Ulvan Oligosaccharides}

The ulvan extract $(1 \%, w / v)$ was mixed with crude enzymes solutions from both P. vesicularis MA103 (10\%, v/v) and A. salmonicida MAEF108 (5\%,v/v), and incubated at $37^{\circ} \mathrm{C}$ for $24 \mathrm{~h}$ to produce ulvan hydrolysate. In our preliminary results, we tested different hydrolysis times and the highest reducing sugars in the hydrolysate were obtained at $24 \mathrm{~h}$ onwards (data not shown). To purify the oligosaccharides from the ulvan hydrolysate, ultrafiltration (3 kDa membrane) was used to collect a low molecular weight fraction of saccharides, which was named ulvan oligosaccharides (UOS).

\subsection{Proximate Analysis and Chemical Composition Analyses}

The proximate composition of Ulva lactuca was analyzed based on Pádua et al. [29]. The amount of carbohydrate was estimated by subtracting moisture, ash, protein, and lipid contents from $100 \%$. The total sugar content was determined by the phenol- $\mathrm{H}_{2} \mathrm{SO}_{4}$ assay [30] using D-rhamnose (Panreac) as a standard $(0-0.1 \mathrm{mg} / \mathrm{mL})$. The colorimetry of total sugar content was tested on absorbance at $480 \mathrm{~nm}$. The reducing sugar content was measured by the DNS assay [27] using D-rhamnose as a standard (0-1.0 mg/mL). The colorimetry of reducing sugar content was tested on absorbance at $546 \mathrm{~nm}$. The sulfate content of polysaccharides was estimated by turbidimetric method [31], using $\mathrm{Na}_{2} \mathrm{SO}_{4}$ (Panreac) as a standard (0-2.0 mg/mL). Barium chloride-gelatin reagent was prepared 
by following steps. Firstly, $0.5 \mathrm{~g}$ of gelatin (Difco) and $100 \mathrm{~mL}$ of deionized water were mixed with stir thoroughly at $60{ }^{\circ} \mathrm{C}$. Secondly, the gelatin solution was cooled at $4{ }^{\circ} \mathrm{C}$ for $16 \mathrm{~h}$. Finally, $0.5 \mathrm{~g}$ of $\mathrm{BaCl}_{2} \cdot 2 \mathrm{H}_{2} \mathrm{O}$ (Panreac) into gelatin solution was added and mixed evenly. The colorimetry of sulfate content was tested on absorbance at $360 \mathrm{~nm}$. The analysis of uronic acid content was tested as described [32], using glucuronic acid (Sigma) as a standard $(0-0.5 \mathrm{mg} / \mathrm{mL})$. The colorimetry of uronic acid content was tested on absorbance at $530 \mathrm{~nm}$. Total phenols content was analyzed with the colorimetrical method [33], using gallic acid (Sigma) as standard (0-2.5 mg/mL). The colorimetry of total phenols content was tested on absorbance at $735 \mathrm{~nm}$.

\subsection{Fourier Transform Infrared Spectroscopy (FT-IR)}

To evaluate the chemical structure of the ulvan extract and the UOS, samples were analyzed by Fourier transform infrared spectroscopy (FT-IR) (Tensor 27, Bruker Optics, Ettlingen, Bruker, Germany), as described by Cerqueira et al. [34]. Pre-dried sample $\left(105^{\circ} \mathrm{C} / 16 \mathrm{~h}\right.$ ) was mixed with $\mathrm{KBr}$ (Panreac) $(1: 99, w: w)$ and then formed into a disk under vacuum condition by manual pressing. The FT-IR spectrum were recorded using at least 16 scans with $8 \mathrm{~cm}^{-1}$ resolution in the spectral range of $4000-400 \mathrm{~cm}^{-1}$.

\subsection{Molecular Weight Distribution}

The molecular weight distribution of the UOS was analyzed by high-performance size exclusion chromatography (HPSEC) [35]. The HPSEC system is equipped with a column of Asahipak GS-320 HQ (7.5 × $300 \mathrm{~mm}$, Shodex, Munich, Germany; Shodex $)$ at $30{ }^{\circ} \mathrm{C}$, pump (L-2130, Hitachi, Tokyo, Japan), and refractometer index detector (RI-930, Jasco, Tokyo, Japan). Samples $(20 \mu \mathrm{L})$ were carried with deionized water containing $0.02 \% \mathrm{NaN}_{3}$ at a flow rate of $0.4 \mathrm{~mL} / \mathrm{min}$. The standard curve for measuring the molecular distribution is built by $2 \mathrm{mg} / \mathrm{mL}$ of Pullulan P-50 (47,100 Da), Pullulan P-20 (21,100 Da), Pullulan P-10 (9600 Da), Pullulan P-5 (6100 Da), maltoheptaose (1153 Da), maltohexaose (990.86 Da), maltopentaose (828.72 Da), maltotetraose (666.58 Da), and maltotriose (504.44 Da).

\subsection{Antioxidant Activity}

\subsubsection{DPPH Free Radical Scavenging Activity}

DPPH radical scavenging activity for the ulvan extract and the UOS was measured as described in Zhang et al. [36] with slight modifications. $100 \mu \mathrm{L}$ of the ulvan extract or the UOS was mixed with $100 \mu \mathrm{L}$ of $0.1 \mathrm{mM}$ DPPH (Sigma) (DPPH was dissolved in anhydrous methanol), respectively. The mixtures were mixed and then incubated in the dark environment at $26^{\circ} \mathrm{C}$ for 30 min prior to absorbance measurement at $517 \mathrm{~nm}$. Ascorbic acid (Panreac) was used as a positive control in the test of DPPH radical scavenging activity. DPPH radical scavenging activity is calculated as follow:

$$
\text { DPPH radical scavenging activity }(\%)=\left[1-\frac{(\mathrm{S}-\mathrm{B})}{\mathrm{C}}\right] \times 100
$$

where $S$ is the absorbance of the sample (sample + DPPH) at $517 \mathrm{~nm}$, B is the absorbance of the blank (sample + anhydrous methanol) at $517 \mathrm{~nm}$, and $\mathrm{C}$ is the absorbance of the control (deionized water + DPPH) at $517 \mathrm{~nm}$.

\subsection{2. $\mathrm{Fe}^{2+}$ Chelating Activity}

Measurement of $\mathrm{Fe}^{2+}$ chelating activity for the ulvan extract and the UOS was accomplished as indicated in Dinis et al. [37] with slight modifications. $200 \mu \mathrm{L}$ of the ulvan extract or the UOS was mixed with $20 \mu \mathrm{L}$ of $\mathrm{FeCl}_{2} \cdot 4 \mathrm{H}_{2} \mathrm{O}(2 \mathrm{mM})$ (Panreac) and incubated for $30 \mathrm{s.} 40 \mu \mathrm{L}$ of ferrozine $(5 \mathrm{mM}$ ) (Panreac) was added into the mixture to react for $20 \mathrm{~min}$, and the absorbance at $562 \mathrm{~nm}$ was measured. Ethylenediaminetetraacetic acid (EDTA) 
(Panreac) was used as a positive control. The $\mathrm{Fe}^{2+}$ chelating activity is determined by the following equation:

$$
\mathrm{Fe}^{+} \text {chelating activity }(\%)=\left(1-\frac{\mathrm{S}}{\mathrm{C}}\right) \times 100
$$

where $S$ is the absorbance of the sample group at $562 \mathrm{~nm}$, and $C$ is the absorbance of control group (deionized water) at $562 \mathrm{~nm}$.

\subsubsection{Reducing Power}

Reducing power for the ulvan extract and the UOS was determined as described in Wang et al. [38] with slight modifications. $250 \mu \mathrm{L}$ of the ulvan extract or the UOS was mixed with $250 \mu \mathrm{L}$ of phosphate buffer $(0.2 \mathrm{M}, \mathrm{pH} 6.6)$ and $250 \mu \mathrm{L}$ of $\mathrm{K}_{3} \mathrm{Fe}(\mathrm{CN})_{6}(1 \%, w / v)$ (Panreac), and incubated at $50{ }^{\circ} \mathrm{C}$ for $20 \mathrm{~min}$. After cooling, $250 \mu \mathrm{L}$ of trichloroacetic acid $(10 \%, w / v)$ (Panreac) was added to the mixture to terminate the reaction. The mixture was centrifuged at $900 \times g$ for $5 \mathrm{~min}$ if any precipitation was observed. The supernatant solution was mixed with $500 \mu \mathrm{L}$ of deionized water and $100 \mu \mathrm{L}$ of $\mathrm{FeCl}_{3}(0.1 \%, w / v)$ (Panreac), and left in the dark for $10 \mathrm{~min}$. Finally, the absorbance was measured at $700 \mathrm{~nm}$, and ascorbic acid was used as a positive control.

\subsection{Angiotensin I-Converting Enzyme Inhibitory (ACEI)}

The ACE inhibitory activity was determined based on the reduced percentage of the peak area of hippuric acid (HA) by using reversed-phase high-performance liquid chromatography (RP-HPLC) method [39]. The RP-HPLC system was equipped with a column of Luna C18 (4.6 × $250 \mathrm{~mm}$, Phenomenex, Torrance, CA, USA), pump (model L-7100, Hitachi, Tokyo, Japan), and UV/Visible detector was monitored at $228 \mathrm{~nm}$ (UV/Visible detector 118, Gilson Medical Electronics, Villiers-le-Bel, France). The column was eluted with $50 \%(v / v)$ methanol (Panreac) containing $0.1 \%(v / v)$ trifluoroacetic acid (TFA) (Panreac) at a flow rate of $0.8 \mathrm{~mL} / \mathrm{min}$.

$15 \mathrm{mM}$ Hippuryl-L-histidyl-L-leucine (HHL) (Sigma) and $53.2 \mathrm{mU} / \mathrm{mL}$ rabbit lung ACE (Sigma) were prepared in $100 \mathrm{mM}$ sodium borate buffer ( $\mathrm{pH} 8.3$ ) containing $300 \mathrm{mM}$ $\mathrm{NaCl}$, respectively. $75 \mu \mathrm{L}$ of the ulvan extract and the UOS was mixed with $75 \mu \mathrm{L}$ of rabbit lung ACE solution individually, and the mixture was incubated $37^{\circ} \mathrm{C}$ for $10 \mathrm{~min}$. Next, $75 \mu \mathrm{L}$ of $15 \mathrm{mM}$ HHL solution was added to the mixture and then incubated it in a water bath at $37^{\circ} \mathrm{C} / 100 \mathrm{rpm}$ for $30 \mathrm{~min}$. Afterward, the enzymatic reaction was terminated by adding $250 \mu \mathrm{L}$ of $1 \mathrm{M} \mathrm{HCl}$. Prior to RP-HPLC analysis, each reacted sample was filtered through a $0.22 \mu \mathrm{m}$ filter. Finally, $10 \mu \mathrm{L}$ filtrate was injected into the column for HA analysis. The ACE inhibitory activity (\%) is calculated using the following equation:

$$
\text { ACE inhibition }(\%)=\left(\frac{C-A}{C-B}\right) \times 100
$$

where A refers to the absorbance of the reaction mixture (sample), B refers to the absorbance when the stop solution was added before the reaction occurred (blank), and C refers to the absorbance of the buffer (control).

\subsection{Data Analysis}

Data were expressed as means \pm SD. Moreover, all measurements were replicated three times. The data were analyzed by one-way analysis (ANOVA), and Duncan's multiple range test was applied to the result, where $p<0.05$ indicates the significant differences.

\section{Results and Discussion}

\subsection{Proximate Analysis of Ulva Lactuca}

The structural composition of seaweeds is affected by harvested season, location, and species [40]. Powder of Ulva lactuca contained $11.4 \%$ of moisture, $32.4 \%$ of ash, $10.8 \%$ 
of crude protein, $0.3 \%$ of crude fat, and $45.1 \%$ of carbohydrates (Table 1 ). In dry matter, Ulva lactuca contained $50.9 \%$ of carbohydrates. The proximate analysis showed that carbohydrates were the main component in dried Ulva lactuca. This result was similar to previous reports [29,41], indicating that $67.32-70.31 \%$ and $54.90 \%$ of carbohydrates were contained in the dry Ulva lactuca, respectively. Like other seaweeds, the carbohydrate content of Ulva lactuca varies with harvested season, source, and physiological maturity [42].

Table 1. The proximity analysis of dried Ulva lactuca.

\begin{tabular}{ccc}
\hline Components & Content $(\%$, Ulva Powder) & Content (\%, Dry Weight) \\
\hline Moisture & $11.4 \pm 0.0$ & - \\
Ash & $32.4 \pm 0.3$ & 36.6 \\
Crude protein & $10.8 \pm 0.7$ & 12.1 \\
Crude fat & $0.3 \pm 0.1$ & 0.4 \\
Carbohydrate $^{1}$ & 45.1 & 50.9 \\
\hline
\end{tabular}

${ }^{1}$ Carbohydrate $=100 \%-(\%$ of moisture + ash + crude protein + crude fat $)$. Values are expressed as mean \pm standard deviation $(n=3)$.

\subsection{Marine Bacteria Enzymes Degrading the Ulvan Extract from Ulva}

Our previous research indicated that Pseudomonas vesicularis MA103 and Aeromonas salmonicida MAEF108 could produce different enzymes to degrade polysaccharides into oligosaccharides [43]. In this study, we aimed to collect the crude enzymes from these two strains for degradation of ulvan. The marine bacteria Pseudomonas vesicularis MA103 and Aeromonas salmonicida MAEF108 were cultivated the modified marine broth added with the ulvan extract, and the crude microbial enzymes were collected for the activities of ulvanolytic enzyme, amylase, cellulase, and xylanase (Figure 1).

Figure 1A shows the changes in enzyme activity during the incubation of MA103. Amylase and xylanase's performances were better after three days of culture, $3.78 \mathrm{U} / \mathrm{mL}$ and $2.72 \mathrm{U} / \mathrm{mL}$, respectively. Cellulase showed higher activity $(3.92 \mathrm{U} / \mathrm{mL})$ on day two. During the whole period of incubating MA103, ulvanolytic enzyme could be detected. Finally, the crude enzyme solution of MA103 induced-3 days was chosen, with total enzyme activity of $10.06 \mathrm{U} / \mathrm{mL}$. On the other hand, Figure $1 \mathrm{~B}$ shows the changes in enzyme activities in the MAEF108 culture. Cellulase was indicated the highest activity in two days of culturing, $3.23 \mathrm{U} / \mathrm{mL}$. Activities of ulvanolytic enzyme, amylase, and xylanase had no significant change during incubation of MAEF108. Thus, the crude enzyme solution of MAEF108 induced-2 days was selected, with total enzyme activity of $4.81 \mathrm{U} / \mathrm{mL}$. The enzyme activities changed during MA103 and MAEF108 cultivation for enzyme production. This phenomenon has been observed when MA103 and MAEF108 were cultivated in a different medium for hydrolases production. It was speculated that the changes in enzyme activities during the cultivation of these two marine bacteria might relate to the cell activity and the substrate composition during cultivation.

Converting seaweed polysaccharides to oligosaccharides is a potential process to increase algal products' application in food, agricultural, and other biochemical fields. Enzyme-assistant extraction is considered a valuable technique to acquire bioactive compounds from seaweeds [22]. Using multiple enzymes to extract bioactive compounds from plants or algae may be a proper strategy because the complex cell wall can hinder single enzyme hydrolysis [44]. Research shows that ulvan polysaccharides could be depolymerized by microbial enzymatic hydrolysis. Coste et al. [45] reported that the isolated Alteromonas sp. could grow with ulvan as a sole carbon source and produce ulvan lyase, which can degrade ulvan polysaccharides to oligosaccharides. He et al. [46] indicated that the ulvan of Ulva ohnoi could be degraded into oligosaccharides by the ulvan lyase produced from the isolated Alteromonas sp. KUL17. Our study displayed that two isolated marine bacteria Pseudomonas vesicularis MA103 and Aeromonas salmonicida MAEF108, could produce multiple hydrolytic enzymes that benefit the ulvan degradation. The limitations for large-scale production of oligosaccharides via enzymatic processes could be the high 
cost of enzyme production and purification [47]. In this study, we saved the step for the chromatographic purification of enzymes to reduce the cost. In addition, in the long run, to conduct the seaweed biorefinery concept in the process of oligosaccharide production might further reduce the production cost [48].

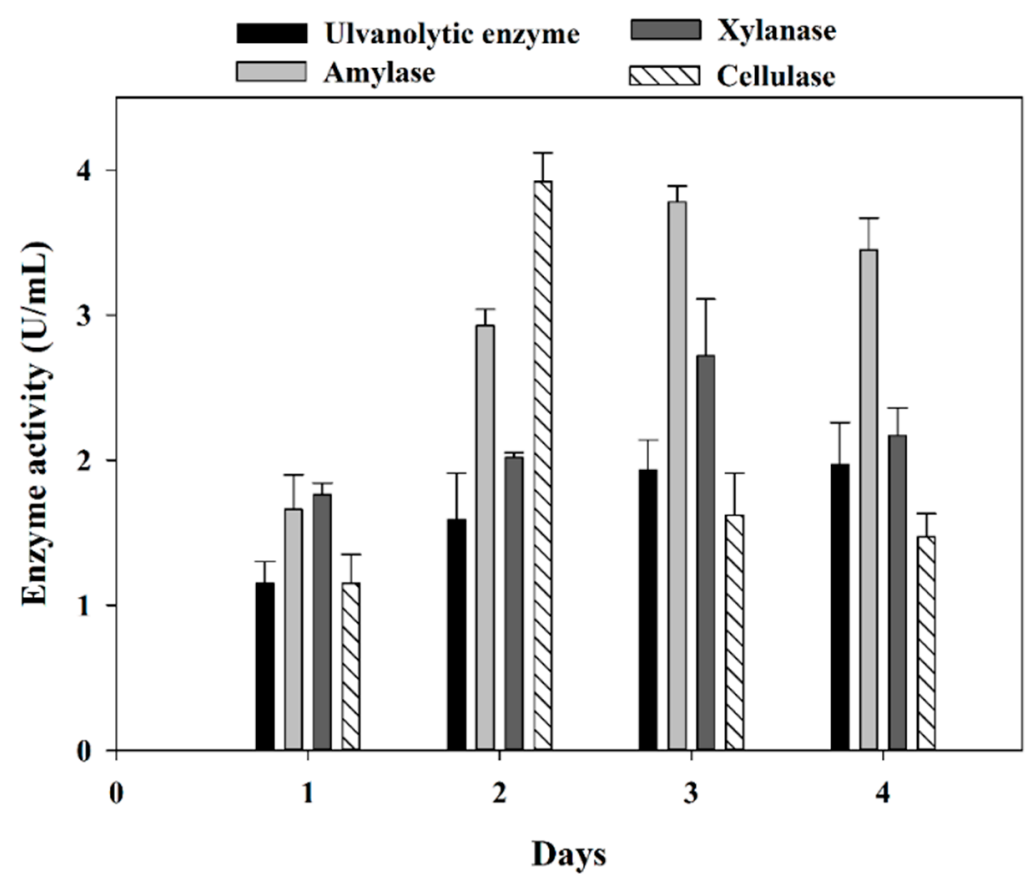

(A)

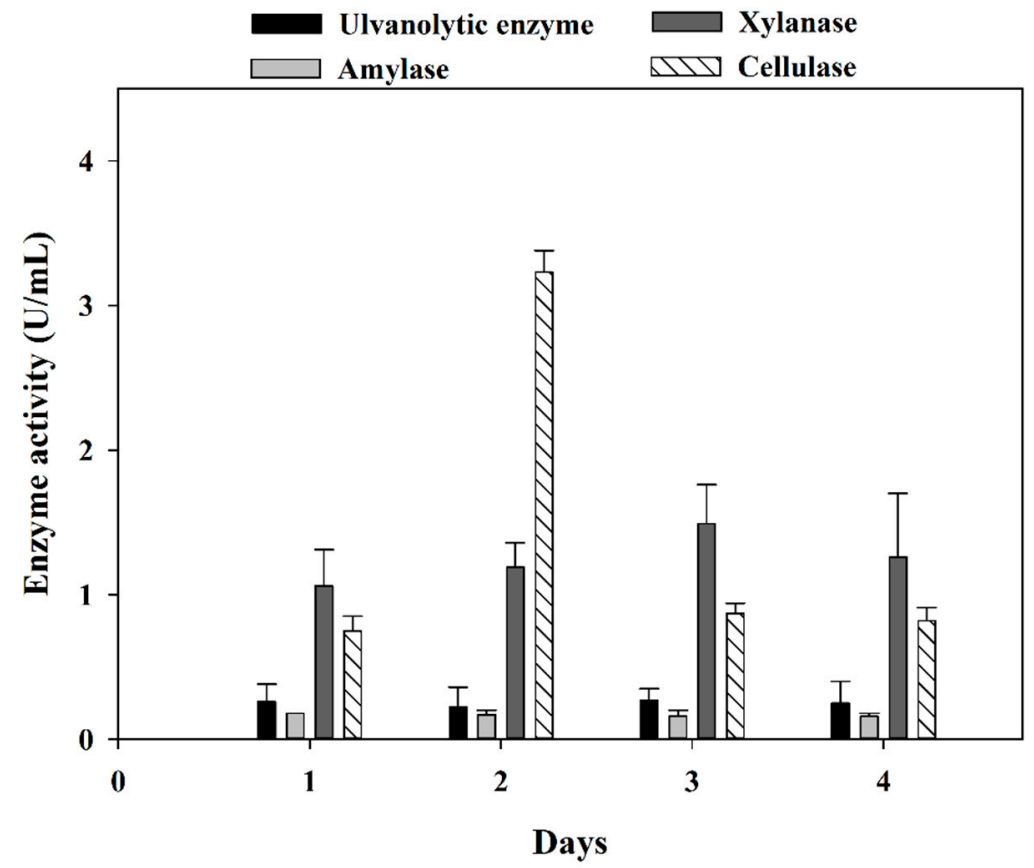

(B)

Figure 1. The enzyme activities of the crude enzyme solution from (A) P. vesicularis MA103 and (B) A. salmonicida MAEF108.

\subsection{Chemical Characteristics of Ulvan and Ulvan Oligosaccharides (UOS)}

Ulvan is the major water-soluble sulfated polysaccharide in Ulva sp. [7,14]. The chemical characteristics and sugar composition of ulvan would be different due to extraction steps $[49,50]$. In this study, the ulvan was extracted by hot water and purified by ultrafiltra- 
tion and ethanol precipitation. The yield and chemical composition of the ulvan extract and the UOS are shown in Table 2.

Table 2. The yield, the chemical compositions, and sulfate/total sugar ratio of ulvan extract and ulvan oligosaccharides (UOS).

\begin{tabular}{cccccc}
\hline \multirow{2}{*}{ Sample } & Yield (\%) $\mathbf{1}^{\mathbf{1}}$ & $\begin{array}{c}\text { Sulfate/Total } \\
\text { Sugar }^{2}\end{array}$ & $\begin{array}{c}\text { Reducing } \\
\text { Sugars }\end{array}$ & Uronic Acid & $\begin{array}{c}\text { Total } \\
\text { Phenols }\end{array}$ \\
\cline { 4 - 6 } & & 0.44 & $3.05 \pm 0.32$ & $30.22 \pm 1.88$ & $0.11 \pm 0.01$ \\
Ulvan extract & $15.89 \pm 0.96$ & 1.78 & $7.17 \pm 0.09$ & $2.54 \pm 0.22$ & $0.73 \pm 0.03$ \\
UOS & $4.69 \pm 0.76$ & &
\end{tabular}

${ }^{1}$ yield $(\%)=($ lyophilized ulvan or UOS $(\mathrm{g}) /$ Ulva powder $(\mathrm{g})) \times 100 .{ }^{2}$ Sul/TS: sulfate/total sugar (average of triplicate). Values are expressed as mean \pm standard deviation $(n=3)$.

The yield of the ulvan extract by our procedure was $15.89 \%$, and the ulvan extract contained reducing sugar (3.05\%), uronic acid $(30.22 \%)$, and total phenols $(0.11 \%)$, and the ratio of sulfate to total sugar of ulvan was 0.44 . The uronic acid contents of ulvan extracts were reported in 9.2-23.8\% with different extraction cascading processes [50].

The crude enzyme solutions of marine bacteria MA103 and MAEF108 were observed to degrade the ulvan extract to the UOS, and the yield of the UOS was $4.69 \%$ (Table 2). The UOS was determined to have reduced sugar, uronic acid, and total phenols at 7.17, 2.54 , and $0.73 \%$, respectively, with a ratio of sulfate to total sugar of the UOS was 1.78 . Our data indicated that the total phenol of the UOS was higher than the ulvan extract. According to Rioux and Turgeon [5], the cell wall model of seaweed is quite complex in that polysaccharides, phenolic compounds, and iodide are interacted and arranged together. Thus, we surmised that enzyme hydrolysis could likely help to expose phenolic compounds from the inner structure to the outside. Fleita et al. [51] indicated that some red seaweed polysaccharides samples were measured higher total phenolic content after the enzymatic hydrolysis. In addition, we observed that the reducing sugar of the UOS was higher than the ulvan extract. The reducing sugar content is commonly considered the indicator for hydrolysis efficiency [52,53]. Our result suggested that the crude enzymes could hydrolyze the ulvan extract due to the increase of reducing sugar content in the UOS.

\subsection{Molecular Weight Distribution}

The HPSEC chromatograms of UOS hydrolyzed from ulvan extract by the crude enzymes were shown in Figure 2. The peak at the retention time of 16.38 min (around $24 \mathrm{kDa}$ ) was observed for the ulvan without hydrolysis in the HPSEC chromatogram (Figure 2A).

As shown in Figure 2B, the predominant peaks for the UOS were eluted at $16.70 \mathrm{~min}$, $20.25 \mathrm{~min}$, and $25.87 \mathrm{~min}$, which their molecular weights were approximately $24 \mathrm{kDa}$, $6 \mathrm{kDa}$, and $800 \mathrm{Da}$. The molecular weight distribution was mainly located at around 800 Da with its relative ratio of $82 \%$ based on the peak area. The UOS was filtered through a $3 \mathrm{kDa}$ membrane to remove the sugars at higher molecule weights. Although the UOS were collected after ultrafiltration ( $3 \mathrm{kDa}$ cut-off membrane), some samples at around 24 and $6 \mathrm{kDa}$ were observed. This result was reproducible, even when the filtration step for the UOS production was repeated. We speculated that pore size at $3 \mathrm{kDa}$ for the cutoff membrane in the ultrafiltration might not be efficient enough to filter out the samples higher than $3 \mathrm{kDa}$ completely, possibly owing to the linear shape of the oligosaccharides. Some marine bacteria can produce specific enzymes to target and degrade seaweed cell wall structures [54]. For instance, $5 \mathrm{kDa}$ oligosaccharides were obtained by hydrolyzing ulvan with the crude lyase isolated from Alteromonas sp. [45]. The purified ulvan lyase gained from Alteromonas sp. can degrade ulvan into oligosaccharides of the degree of polymerization (DP) 8, 6, 4, and 2 [46], or DP 4 and DP 2 [55]. The molecular weight of oligosaccharides is one of the important characteristics for its biological activities. For example, the molecular weight of chitooligosaccharides is considered as a critical factor for 
its biological activities, such as antioxidant, antimicrobial, and anti-tumor activities [56].

Thus, the molecular weight distribution of the UOS was determined in this study.

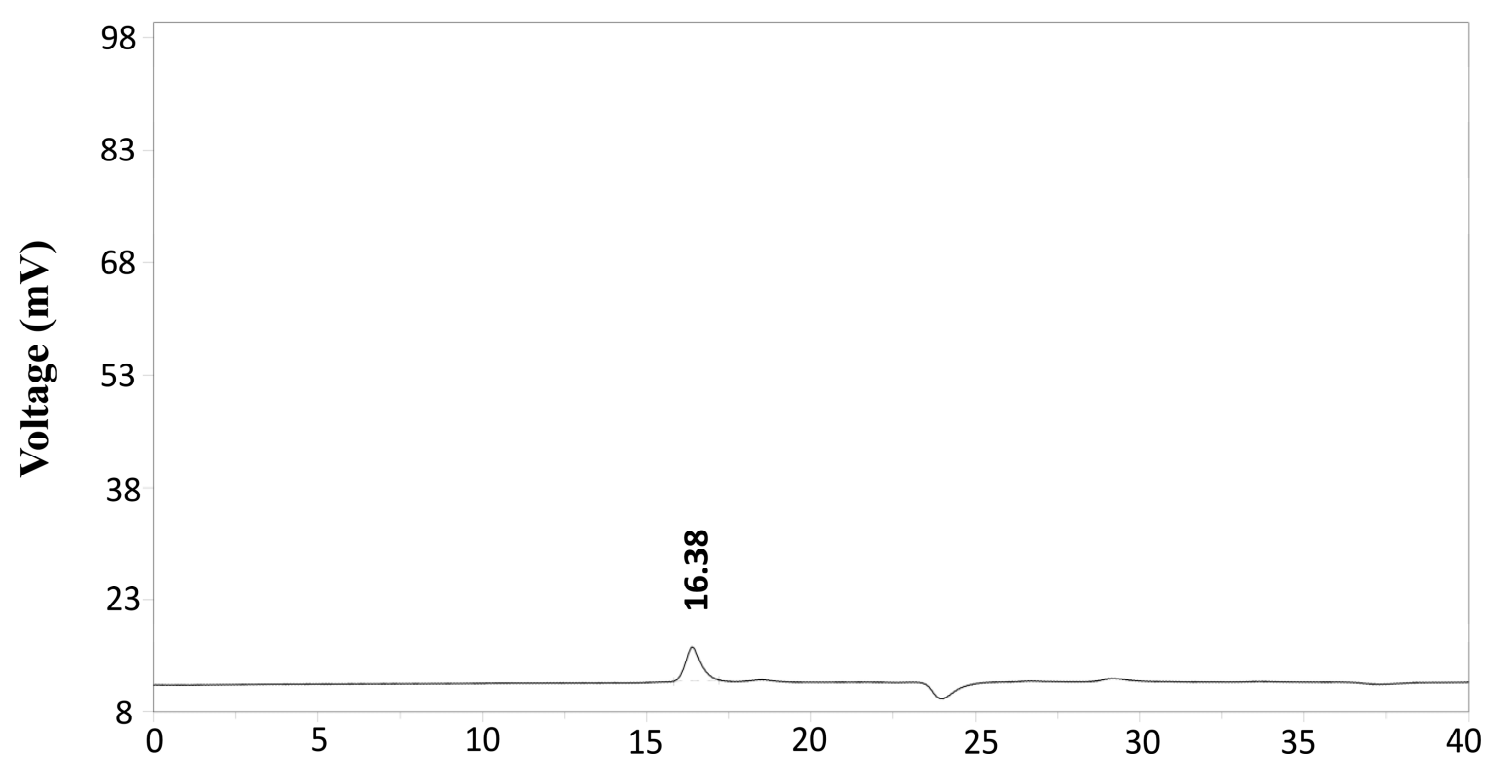

Time (min)

(A)

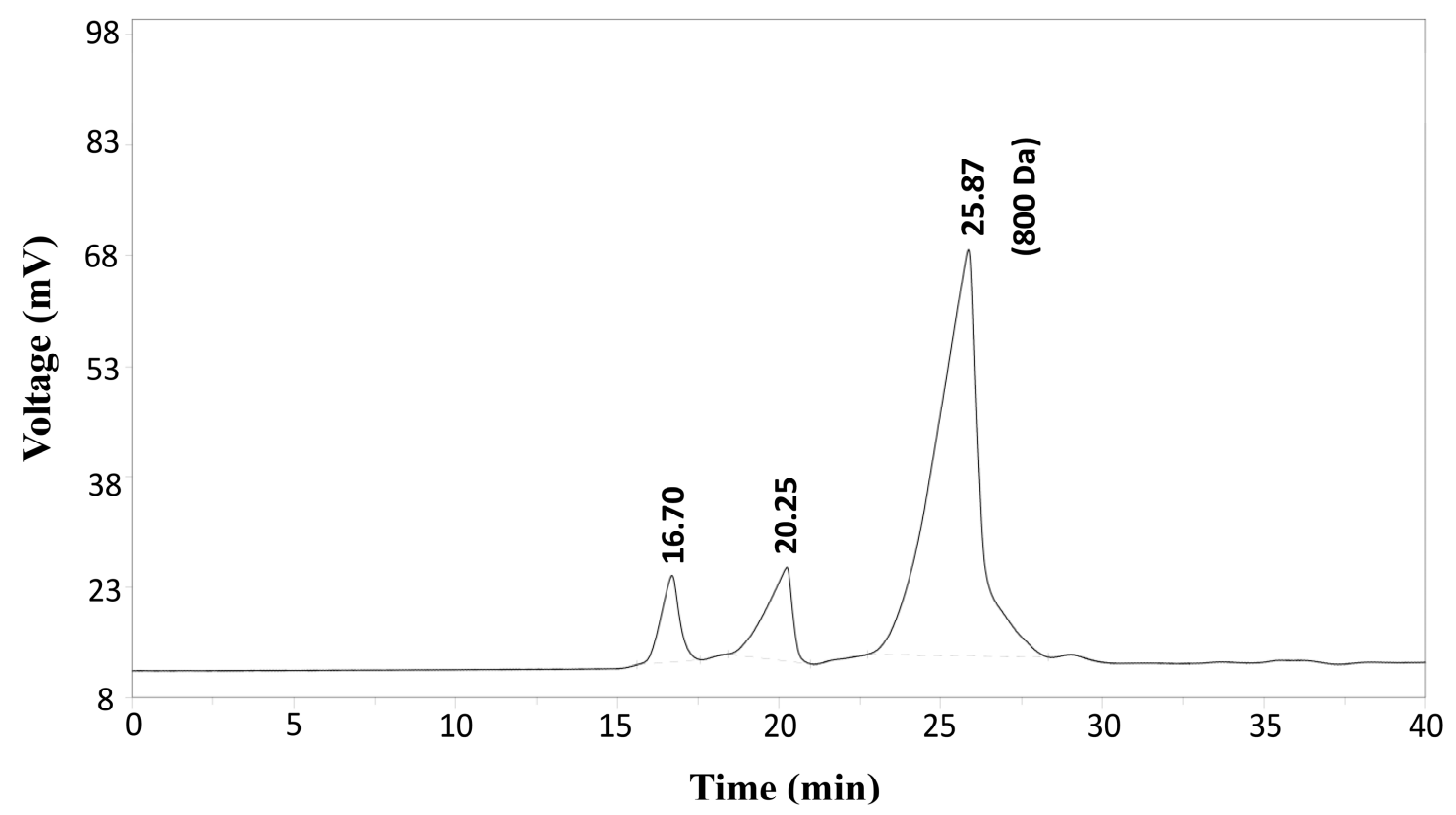

(B)

Figure 2. HPSEC chromatograms of UOS hydrolyzed from ulvan extract by the crude enzymes at $37^{\circ} \mathrm{C}$ for $(\mathbf{A}) 0 \mathrm{~h}$, and (B) $24 \mathrm{~h}$. The samples $(20 \mu \mathrm{L})$ were carried with $\mathrm{ddH}_{2} \mathrm{O}$ containing $0.02 \% \mathrm{NaN}_{3}$ at a flow rate of $0.4 \mathrm{~mL} / \mathrm{min}$. Column: Asahipak GS-320 HQ $\left(7.5 \times 300 \mathrm{~mm}\right.$, Shodex, Munich, Germany; Shodex) at $30^{\circ} \mathrm{C}$. Refractometer index detector (RI-930, Jasco, Tokyo, Japan).

\subsection{FT-IR Analysis}

The FT-IR spectrum of ulvan extract (blue line) is shown in Figure 3. The bands for stretching vibrations were shown at about $3384 \mathrm{~cm}^{-1}, 2937 \mathrm{~cm}^{-1}, 1636 \mathrm{~cm}^{-1}, 1401 \mathrm{~cm}^{-1}$, $1258 \mathrm{~cm}^{-1}, 1053 \mathrm{~cm}^{-1}$ and $849 \mathrm{~cm}^{-1}$. The O-H stretching vibration band was shown at 
3600-3000 $\mathrm{cm}^{-1}$ [57]. In the C-H vibration range, the wavenumber was near $2927 \mathrm{~cm}^{-1}$ [58]. The carboxylate group was shown at two bands that about 1632-1597 $\mathrm{cm}^{-1}$ (asymmetric stretching) and 1448-1400 $\mathrm{cm}^{-1}$ (symmetric stretching) [59]. C-O bonds' wavenumber ranges from 1200 to $1000 \mathrm{~cm}^{-1}$ representing the $\mathrm{C}-\mathrm{OH}$ and $\mathrm{C}-\mathrm{O}-\mathrm{C}$ stretching in sugar ring and glycosidic bond [60]. The sulfate group was considered as the basis of biological activity in seaweed polysaccharides and oligosaccharides [61]. The $\mathrm{S}=\mathrm{O}$ stretching vibration band showed at $1260-1240 \mathrm{~cm}^{-1}$ [62]. Overall, several characteristic peaks $\mathrm{O}-\mathrm{H}, \mathrm{C}-\mathrm{H}, \mathrm{C}=\mathrm{O}, \mathrm{C}-\mathrm{O}$, and $\mathrm{S}=\mathrm{O}$ were identified in the ulvan extract via FT-IR.

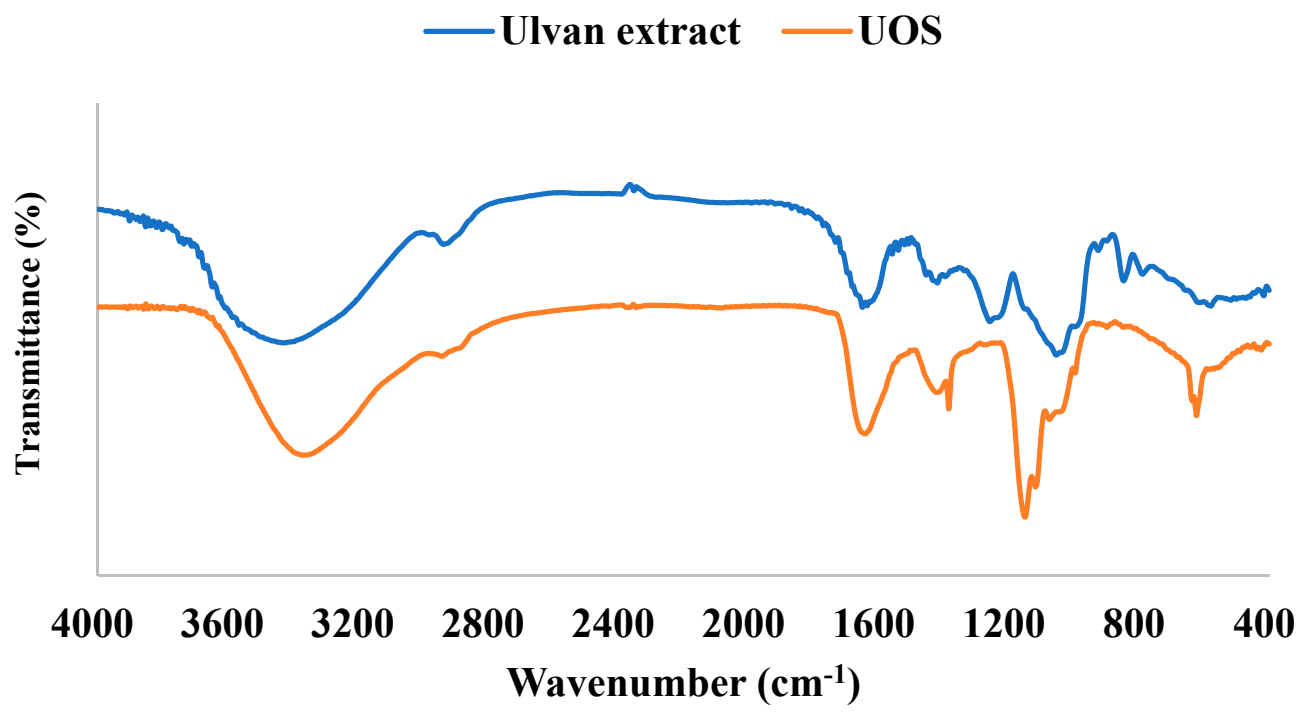

Figure 3. FT-IR chromatogram of ulvan extract (blue) and UOS (orange). (Sample:KBr = 1:99; wave range: $400-4000 \mathrm{~cm}^{-1}$ ).

The FT-IR spectrum of UOS (orange line) was shown stretching vibrations at about $3369 \mathrm{~cm}^{-1}, 1640 \mathrm{~cm}^{-1}, 1420 \mathrm{~cm}^{-1}, 1385 \mathrm{~cm}^{-1}, 1150 \mathrm{~cm}^{-1}, 1119 \mathrm{~cm}^{-1}$ and $625 \mathrm{~cm}^{-1}$ (Figure 3). The sulfate groups of the UOS vibrated at $1385 \mathrm{~cm}^{-1}$ (asymmetric stretching) and $1150 \mathrm{~cm}^{-1}$ (symmetric stretching), according to Oliveira et al. [63]. Like the ulvan extract, $\mathrm{UOS}$ also exhibited $\mathrm{O}-\mathrm{H}$ bonds, $\mathrm{C}=\mathrm{O}$ (symmetry and asymmetry), $\mathrm{C}-\mathrm{O}$, and $\mathrm{S}=\mathrm{O}$. The results demonstrated that enzymatic hydrolysis would not remove the specific functional groups when polysaccharides were degraded to oligosaccharides.

\subsection{Antioxidant Activities}

3.6.1. DPPH (2,2-Diphenyl-1-Picrylhydrazyl) Radical Scavenging Assay

$\mathrm{DPPH}$ assay is used to evaluate the sample's radical scavenging ability and assess whether it is a radical-scavenging antioxidant [64]. As shown in Figure 4A, the positive control vitamin C $(0.01 \mathrm{mg} / \mathrm{mL})$ of DPPH scavenging ability was $73.86 \%$. The result suggested that the scavenging activity of the UOS was a dose-dependent manner from $1.25 \mathrm{mg} / \mathrm{mL}$ to $10 \mathrm{mg} / \mathrm{mL}$. At the same concentration $10 \mathrm{mg} / \mathrm{mL}$, the ulvan extract $(52.46 \%)$ demonstrated better DPPH scavenging ability than the UOS (27.27\%). Cheng et al. [65] indicated that the uronic acid content of different tea polysaccharides conjugate fractions would affect their antioxidant properties. Furthermore, high uronic acid content in polysaccharide fractions had been demonstrated the greater free radical scavenging activities [66]. In DPPH assay, DPPH would lose absorbance by combining an odd electron from hydrogen or electron-donating compounds via hydrogen atom transfer or single electron transfer [67]. Uronic acid, one of units on the ulvan and the UOS, contains hydrogen groups. From our results, we observed that the ulvan extract had higher uronic acid content $(30.22 \%)$ than the UOS (2.54\%). As a result, it was likely due to the higher uronic acid content that the ulvan extract could express stronger DPPH scavenging ability than the UOS in this study. 


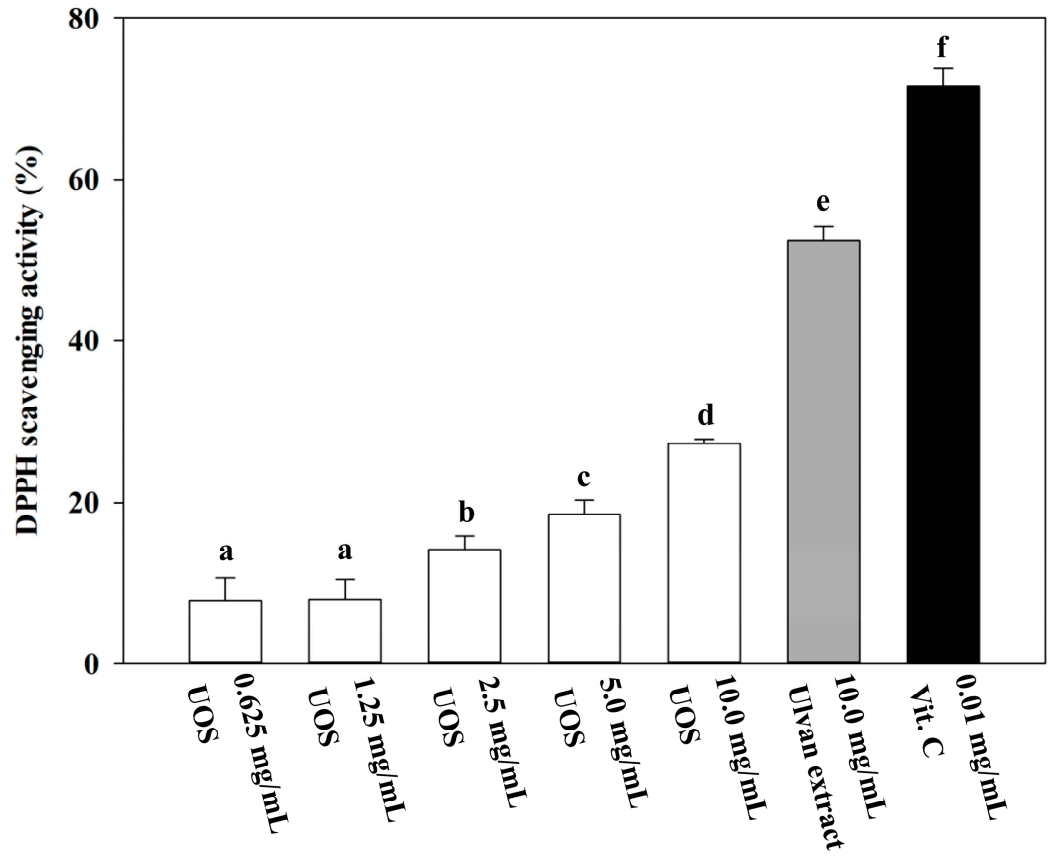

(A)

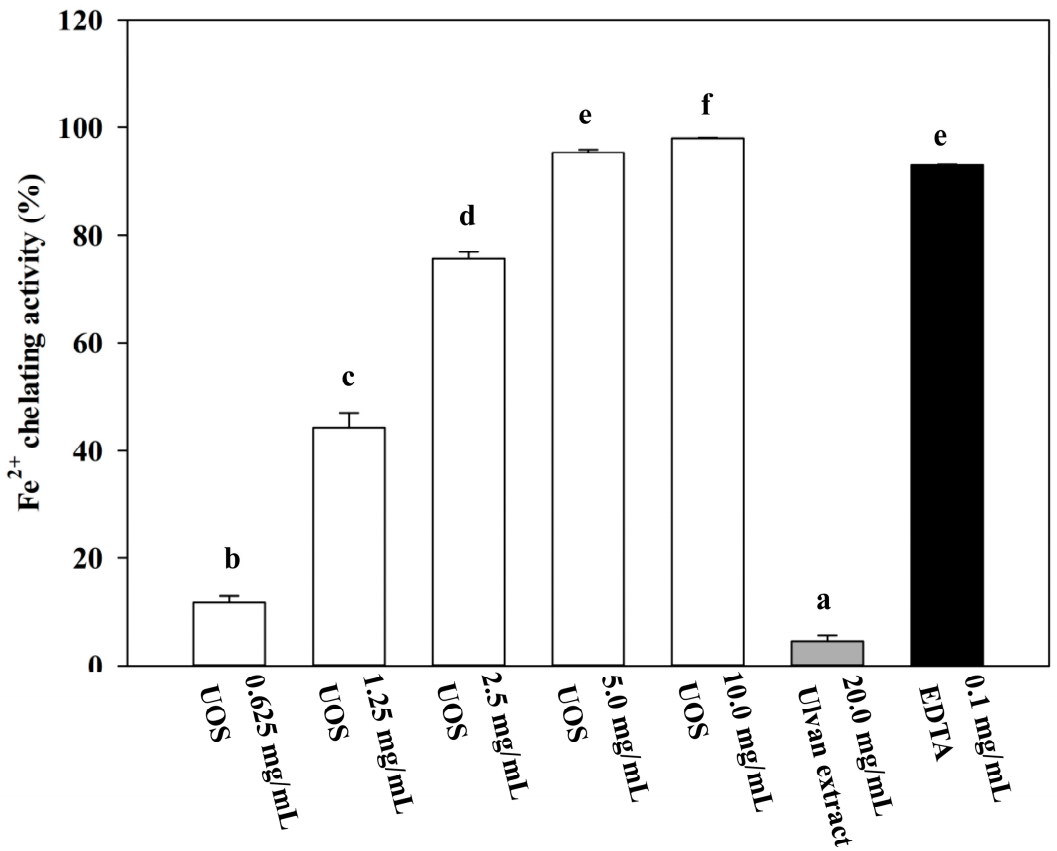

(B)

Figure 4. Cont. 


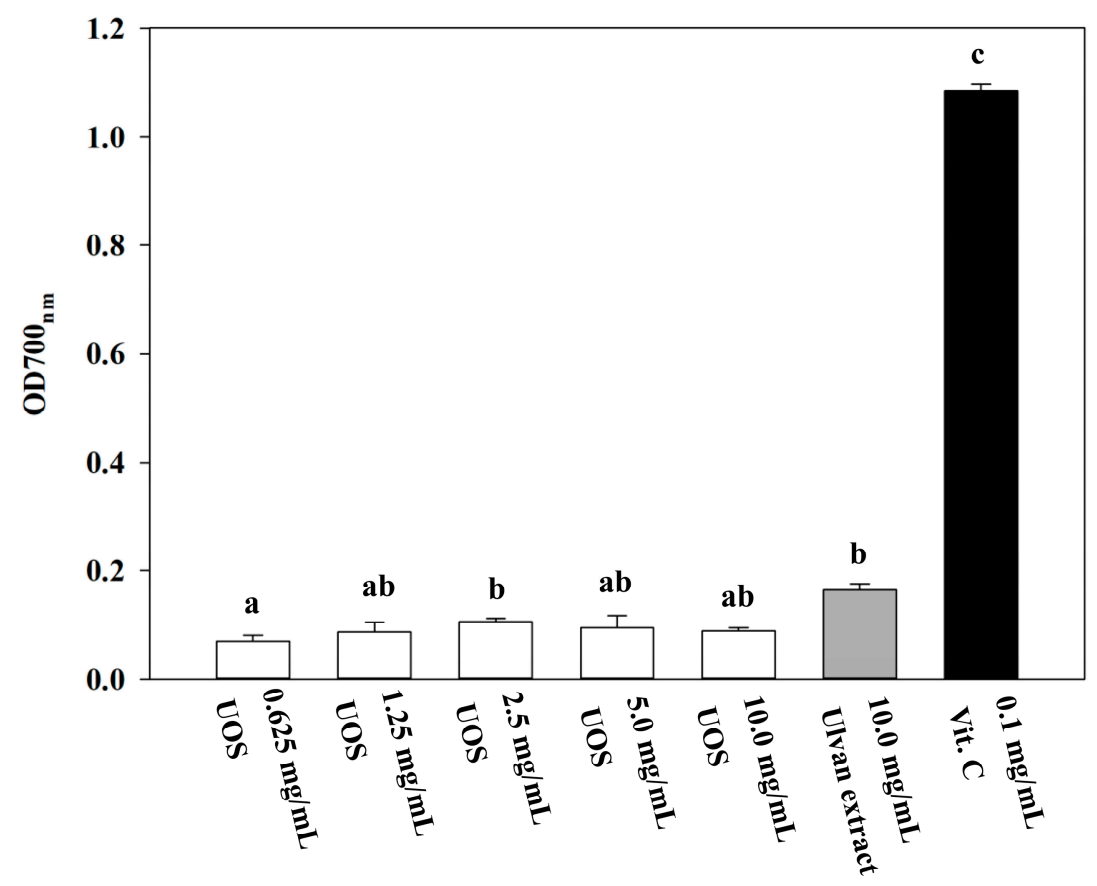

(C)

Figure 4. Antioxidant activities of (A) DPPH scavenging activity, (B) ferrous chelating activity, and (C) reducing powder on ulvan extract and ulvan oligosaccharides (UOS). DPPH assay: absorbance was measured at $517 \mathrm{~nm}$. Ferrous ion chelating assay: absorbance was measured at $562 \mathrm{~nm}$. Reducing power assay: absorbance was measured at $700 \mathrm{~nm}$. Bars with different letters are statistically different $(p<0.05)$.

\subsection{2. $\mathrm{Fe}^{2+}$ Chelating Assay}

The ferrous ion chelating abilities of ulvan extract and UOS are shown in Figure 4B. The effect of UOS on ferrous ion chelating assay displayed a dose-dependence manner from $0.625 \mathrm{mg} / \mathrm{mL}$ to $5.0 \mathrm{mg} / \mathrm{mL}$. Furthermore, the ferrous ion chelating effect of the UOS $(10 \mathrm{mg} / \mathrm{mL})$ was $97.98 \%$, and the positive control EDTA $(0.1 \mathrm{mg} / \mathrm{mL})$ was $93.06 \%$. The result indicated that the UOS had a remarkable ability to chelate ferrous ions. On the other hand, the ulvan extract had a lower chelating ability that was $4.62 \%$ at $20 \mathrm{mg} / \mathrm{mL}$. Overall, the UOS demonstrated a significant chelating ability on ferrous ion than the ulvan extract. The reason might relate to the ratio of sulfate group and total sugar content in saccharides. In this study, the sulfate/total sugar ratio of the ulvan oligosaccharides (1.78) is higher than ulvan (0.44). The sulfate to total sugar ratio of seaweed polysaccharides could affect their antioxidant activities [16]. Biological compounds with the specific functional group of negative charges may have a strong ability in chelating ferrous ions, such as chitosan oligosaccharides and fucoidan oligosaccharides [68]. The sulfated polysaccharide from Gracilaria caudata (red seaweed) had a strong chelating ability when $0.1 \mathrm{mg} / \mathrm{mL}$ was tested, and its chemical composition had the lowest total sugar/sulfate ratio compared to other sulfated polysaccharides [69]. In addition, Dinis et al. [37] indicated that lipid peroxidation could be inhibited by reducing metal ion catalysts (e.g. iron) with chelating agents. Compounds with sulfate group of negative charge might be able to stick to ferrous ion and reduce the formation of a ferrozine-ferrous complex in this assay. Based on our results and references, the ratio of sulfate to total sugar of the UOS might play an important role on its performance of ferrous ion chelating ability.

\subsubsection{Reducing Power Assay}

The result of Figure $4 \mathrm{C}$ was indicated that the UOS displayed the dose-independent effect on reducing power assay. The absorbance of the ulvan extract and the UOS were 
0.17 at $10 \mathrm{mg} / \mathrm{mL}$ and 0.11 at $2.5 \mathrm{mg} / \mathrm{mL}$, respectively. Both saccharides obtained from Ulva sp. did not show great reducing power than the positive control (Vitamin C). The reducing power of vitamin C was 1.08 at $0.1 \mathrm{mg} / \mathrm{mL}$. Similarly, Wang et al. [38] pointed out that the sulfated polysaccharides from brown seaweed Laminaria japonica displayed poor reducing powder, compared to Vitamin C and butylated hydroxyanisole (BHA). In the reducing power assay, the sample's reducing capability was ascribed to the presence of reductones [38]. In other words, reductones can react with the free radicals and donate hydrogen atoms that breaks free radical chains and exerts antioxidant activities [70]. In this study, the ulvan extract and the UOS were not showing higher reducing power than vitamin C, possibly because of the lack of reductone groups. However, further structure characterization of the ulvan extract and the UOS needs to be conducted to confirm the functional groups for evaluating the reducing power assay.

\subsection{ACE Inhibition}

Bioactive peptides, sulfated polysaccharides, and polyphenols are natural ACE inhibitors from bio-resources $[39,71,72]$. Seaweed is a potential source for producing ACE inhibitors, such as its protein hydrolysates, peptides [73-75], and polyphenols (e.g., fucoxanthin and phlorotannin) [76,77]. However, very few oligosaccharides from seaweed origins have been reported to possess ACE-inhibition. Most researches for marine oligosaccharides on ACE-inhibition are the chitooligosaccharides, generated from hydrolysis of chitosan [78]. Chaki et al. [79] reported that sodium alginate oligosaccharides could reduce blood pressure, although the oligosaccharides did not show any ACE inhibitory activity. To our knowledge, this is the first study to demonstrate the UOS with ACE inhibitory activity.

As shown in Table 3, UOS expressed a higher inhibitory efficiency ratio (IER) (6.43) than the ulvan extract (0.48). In addition, UOS showed an ACE inhibition of 81.86, 50.18, and $38.78 \%$, at a concentration of $12.5 \mathrm{mg} / \mathrm{mL}, 8.0 \mathrm{mg} / \mathrm{mL}$, and $6.0 \mathrm{mg} / \mathrm{mL}$ respectively, indicating a dose-dependent manner. It has been reported that sugar-like molecules were likely to bind a tunnel directed toward the active site of ACE and then inhibited the enzyme activity [80]. In this study, the bioactive UOS, containing $>80 \%$ oligosaccharides at an average molecular weight of $800 \mathrm{Da}$, was demonstrated antioxidant and ACE-inhibiting activities. Song et al. [81] indicated that the konjac oligosaccharide with a molecular weight of 666 Da exhibited inhibition activity on ACE in a dose-dependent manner; in addition, half deacetylated chitooligosaccharides in the molecular weight of 1000 to 5000 Da showed its ACE-inhibition activity, indicating the potential of oligosaccharides for ACE-inhibition. However, based on our data, we could not rule out the possibility that the oligosaccharides at $6 \mathrm{kDa}$ and $24 \mathrm{kDa}$ might possess antioxidant and ACE-inhibition activities. Further purification and bioactivity investigations for the UOS will be needed for confirmation. Oligosaccharides have been demonstrated for several applications, such as food and cosmetic products; furthermore, they also can be used as prebiotics and dietary fibers for bacterial and animal feeds [47]. The research for ulvan oligosaccharides and its applications remains limited. In this study, we offered the results for the biological activities of the UOS. Further characterizations of the UOS need to be investigated to promote the potential applications for the UOS. 
Table 3. ACE inhibition on ulvan extract and ulvan oligosaccharides (UOS).

\begin{tabular}{|c|c|c|c|}
\hline Sample & $\begin{array}{l}\text { Sample Conc. } \\
\quad(\mathrm{mg} / \mathrm{mL})\end{array}$ & Inhibition (\%) & $\operatorname{IER}(\% / \mathrm{mg} / \mathrm{mL})$ * \\
\hline \multirow[t]{2}{*}{ Ulvan extract } & 50.0 & $18.41 \pm 5.21^{\mathrm{d}}$ & $0.48 \pm 0.16$ \\
\hline & 25.010 .0 & $\begin{array}{c}14.71 \pm 6.73^{\mathrm{d}} \\
0\end{array}$ & \\
\hline \multirow[t]{3}{*}{ UOS } & 12.5 & $81.86 \pm 2.12^{\mathrm{a}}$ & $6.43 \pm 0.14$ \\
\hline & 8.0 & $50.18 \pm 2.14^{b}$ & \\
\hline & 6.0 & $38.78 \pm 0.51^{\mathrm{c}}$ & \\
\hline
\end{tabular}

\section{Conclusions}

Much attention has been drawn to explore valuable substances from seaweeds with bioactive activities. We extracted polysaccharides from green seaweed Ulva lactuca and produce the ulvan oligosaccharides (UOS) by using crude enzymes solutions from two isolated marine bacteria, which would reduce the cost of enzymes for enzymatic hydrolysis. To best our knowledge, this is the first paper to demonstrate the bioactive UOS can be produced from Ulva lactuca via multiple hydrolases. In addition, the chemical compositions of ulvan extract and UOS were investigated, and our FTIR data indicated that both ulvan extract and UOS had hydroxyl group, sulfate group, and other functional groups. Finally, the biological functions were evaluated for ulvan extract and the UOS in terms of antioxidant and ACE-inhibiting activities. As compared with the ulvan extract, UOS exhibited greater ACE inhibition and ferrous ion chelating ability. Overall, this research provided a practical, environmentally friendly, and low-cost approach to prepare UOS with biological activities.

Author Contributions: C.-L.P. conceived and designed the experiments; Y.-H.R.H. performed the experiments; Y.-H.R.H., C.-L.P., G.-W.C. and H.-T.V.L. analyzed the data; Y.-H.R.H., C.-L.P. and H.-T.V.L. wrote the paper. All authors have read and agreed to the published version of the manuscript.

Funding: This research is supported by the research project 106AS-12. 3. 1-ST-a8 from the Council of Agriculture, Executive Yuan, R.O.C. This research was funded by the Center of Excellence for the Oceans, National Taiwan Ocean University from The Featured Areas Research Center Program within the framework of the Higher Education Sprout Project by the Ministry of Education (MOE) in Taiwan (NTOU-RD-AA-2021-1-02018) and from the Shu-Jih Education Foundation (TIARF106A004).

Conflicts of Interest: The authors declare no conflict of interest.

\section{References}

1. Robic, A.; Sassi, J.F.; Dion, P.; Lerat, Y.; Lahaye, M. Seasonal variability of physicochemical and rheological properties of ulvan in two Ulva species (Chlorophyta) from the Brittany coast. J. Phycol. 2009, 45, 962-973. [CrossRef]

2. Bolton, J.; Robertson-Andersson, D.; Shuuluka, D.; Kandjengo, L. Growing Ulva (Chlorophyta) in integrated systems as a commercial crop for abalone feed in South Africa: A SWOT analysis. J. Appl. Phycol. 2009, 21, 575-583. [CrossRef]

3. Ferdouse, F.; Holdt, S.L.; Smith, R.; Murúa, P.; Yang, Z. The global status of seaweed production, trade and utilization. Globefish Res. Programme 2018, 124, 1-124.

4. Cai, J. Global status of seaweed production, trade and utilization. In Seaweed Innovation Forum Belize, Session 1: Seaweed and Climate Change; Compete Caribbean: Christ Church, Barbados, 2021. Available online: https://www.competecaribbean.org/ belize-seaweed/ (accessed on 18 August 2021).

5. Rioux, L.-E.; Turgeon, S.L. Chapter 7-Seaweed carbohydrates. In Seaweed Sustainability; Tiwari, B.K., Troy, D.J., Eds.; Elsevier: Amsterdam, The Netherlands, 2015; pp. 141-192. [CrossRef]

6. Holdt, S.L.; Kraan, S. Bioactive compounds in seaweed: Functional food applications and legislation. J. Appl. Phycol. 2011, 23, 543-597. [CrossRef]

7. Lahaye, M.; Robic, A. Structure and functional properties of ulvan, a polysaccharide from green seaweeds. Biomacromolecules 2007, 8, 1765-1774. [CrossRef]

8. Robic, A.; Sassi, J.-F.; Lahaye, M. Impact of stabilization treatments of the green seaweed Ulva rotundata (Chlorophyta) on the extraction yield, the physico-chemical and rheological properties of ulvan. Carbohydr. Polym. 2008, 74, 344-352. [CrossRef] 
9. Robic, A.; Rondeau-Mouro, C.; Sassi, J.-F.; Lerat, Y.; Lahaye, M. Structure and interactions of ulvan in the cell wall of the marine green algae Ulva rotundata (Ulvales, Chlorophyceae). Carbohydr. Polym. 2009, 77, 206-216. [CrossRef]

10. Quemener, B.; Lahaye, M.; Bobin-Dubigeon, C. Sugar determination in ulvans by a chemical-enzymatic method coupled to high performance anion exchange chromatography. J. Appl. Phycol. 1997, 9, 179-188. [CrossRef]

11. Lahaye, M.; Brunel, M.; Bonnin, E. Fine chemical structure analysis of oligosaccharides produced by an ulvan-lyase degradation of the water-soluble cell-wall polysaccharides from Ulva sp.(Ulvales, Chlorophyta). Carbohydr. Res. 1997, 304, 325-333. [CrossRef]

12. Ray, B.; Lahaye, M. Cell-wall polysaccharides from the marine green alga Ulva "rigida"(Ulvales, Chlorophyta). Extraction and chemical composition. Carbohydr. Res. 1995, 274, 251-261. [CrossRef]

13. Alves, A.; Sousa, R.A.; Reis, R.L. A practical perspective on ulvan extracted from green algae. J. Appl. Phycol. 2013, 25, 407-424. [CrossRef]

14. Kidgell, J.T.; Magnusson, M.; de Nys, R.; Glasson, C.R. Ulvan: A systematic review of extraction, composition and function. Algal Res. 2019, 39, 101422. [CrossRef]

15. Qi, H.; Zhao, T.; Zhang, Q.; Li, Z.; Zhao, Z.; Xing, R. Antioxidant activity of different molecular weight sulfated polysaccharides from Ulva pertusa Kjellm (Chlorophyta). J. Appl. Phycol. 2005, 17, 527-534. [CrossRef]

16. Peasura, N.; Laohakunjit, N.; Kerdchoechuen, O.; Vongsawasdi, P.; Chao, L.K. Assessment of biochemical and immunomodulatory activity of sulphated polysaccharides from Ulva intestinalis. Int. J. Biol. Macromol. 2016, 91, 269-277. [CrossRef] [PubMed]

17. Tabarsa, M.; You, S.; Dabaghian, E.H.; Surayot, U. Water-soluble polysaccharides from Ulva intestinalis: Molecular properties, structural elucidation and immunomodulatory activities. J. Food Drug Anal. 2018, 26, 599-608. [CrossRef] [PubMed]

18. Pengzhan, Y.; Ning, L.; Xiguang, L.; Gefei, Z.; Quanbin, Z.; Pengcheng, L. Antihyperlipidemic effects of different molecular weight sulfated polysaccharides from Ulva pertusa (Chlorophyta). Pharmacol. Res. 2003, 48, 543-549. [CrossRef]

19. Zhu, B.; Ni, F.; Xiong, Q.; Yao, Z. Marine oligosaccharides originated from seaweeds: Source, preparation, structure, physiological activity and applications. Crit. Rev. Food Sci. Nutr. 2021, 61, 60-74. [CrossRef] [PubMed]

20. Michalak, I.; Chojnacka, K. Chapter 7-Production of seaweed extracts by biological and chemical methods. In Marine Algae extracts: Processes, Products, and Applications; Kim, S.-K., Chojnacka, K., Eds.; Wiley: Hoboken, NJ, USA, 2015; Volume 1, pp. 121-144. [CrossRef]

21. Monlau, F.; Sambusiti, C.; Barakat, A.; Quéméneur, M.; Trably, E.; Steyer, J.-P.; Carrère, H. Do furanic and phenolic compounds of lignocellulosic and algae biomass hydrolyzate inhibit anaerobic mixed cultures? A comprehensive review. Biotechnol. Adv. 2014, 32, 934-951. [CrossRef]

22. Wijesinghe, W.; Jeon, Y.-J. Enzyme-assistant extraction (EAE) of bioactive components: A useful approach for recovery of industrially important metabolites from seaweeds: A. review. Fitoterapia 2012, 83, 6-12. [CrossRef]

23. Wu, S.-C.; Wang, F.-J.; Pan, C.-L. Growth and survival of lactic acid bacteria during the fermentation and storage of seaweed oligosaccharides solution. J. Mar. Sci. Technol. 2007, 15, 104-114. [CrossRef]

24. Alves, A.; Caridade, S.G.; Mano, J.F.; Sousa, R.A.; Reis, R.L. Extraction and physico-chemical characterization of a versatile biodegradable polysaccharide obtained from green algae. Carbohydr. Res. 2010, 345, 2194-2200. [CrossRef] [PubMed]

25. Bailey, M.J.; Biely, P.; Poutanen, K. Interlaboratory testing of methods for assay of xylanase activity. J. Biotechnol. 1992, 23, 257-270. [CrossRef]

26. Bernfeld, P. Amylases, $\alpha$ and $\beta$. Methods Enzymol. 1955, 1, 149-158. [CrossRef]

27. Miller, G.L. Use of dinitrosalicylic acid reagent for determination of reducing sugar. Anal. Chem. 1959, 31, 426-428. [CrossRef]

28. Battelli, M.; Corte, E.D.; Stirpe, F. Xanthine oxidase type D (dehydrogenase) in the intestine and other organs of the rat. Biochem. J. 1972, 126, 747-749. [CrossRef]

29. Pádua, M.d.; Fontoura, P.S.G.; Mathias, A.L. Chemical composition of Ulvaria oxysperma (Kützing) bliding, Ulva lactuca (Linnaeus) and Ulva fascita (Delile). Braz. Arch. Biol. Technol. 2004, 47, 49-55. [CrossRef]

30. Dubois, M.; Gilles, K.A.; Hamilton, J.K.; Rebers, P.t.; Smith, F. Colorimetric method for determination of sugars and related substances. Anal. Chem. 1956, 28, 350-356. [CrossRef]

31. Dodgson, K.; Price, R. A note on the determination of the ester sulphate content of sulphated polysaccharides. Biochem. J. 1962, 84, 106. [CrossRef]

32. Bitter, T. A modified uronic acid carbazole reaction. Anal. Biochem. 1962, 4, 330-334. [CrossRef]

33. Singleton, V.L.; Rossi, J.A. Colorimetry of total phenolics with phosphomolybdic-phosphotungstic acid reagents. Am. J. Enol. Vitic. 1965, 16, 144-158.

34. Cerqueira, M.A.; Souza, B.W.; Simões, J.; Teixeira, J.A.; Domingues, M.R.M.; Coimbra, M.A.; Vicente, A.A. Structural and thermal characterization of galactomannans from non-conventional sources. Carbohydr. Polym. 2011, 83, 179-185. [CrossRef]

35. Liang, W.; Liu, T.; Chang, C.; Pan, C. Bioactivity of $\beta-1,3-x y l a n$ extracted from Caulerpa lentillifera by using Escherichia coli

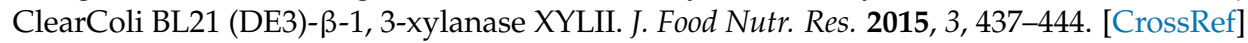

36. Zhang, W.-W.; Duan, X.-J.; Huang, H.-L.; Zhang, Y.; Wang, B.-G. Evaluation of 28 marine algae from the Qingdao coast for antioxidative capacity and determination of antioxidant efficiency and total phenolic content of fractions and subfractions derived from Symphyocladia latiuscula (Rhodomelaceae). J. Appl. Phycol. 2007, 19, 97-108. [CrossRef]

37. Dinis, T.C.; Madeira, V.M.; Almeida, L.M. Action of phenolic derivatives (acetaminophen, salicylate, and 5-aminosalicylate) as inhibitors of membrane lipid peroxidation and as peroxyl radical scavengers. Arch. Biochem. Biophys. 1994, 315, 161-169. [CrossRef] [PubMed] 
38. Wang, J.; Zhang, Q.; Zhang, Z.; Li, Z. Antioxidant activity of sulfated polysaccharide fractions extracted from Laminaria japonica. Int. J. Biol. Macromol. 2008, 42, 127-132. [CrossRef] [PubMed]

39. Chen, G.-W.; Tsai, J.-S.; Pan, B.S. Purification of angiotensin I-converting enzyme inhibitory peptides and antihypertensive effect of milk produced by protease-facilitated lactic fermentation. Int. Dairy, J. 2007, 17, 641-647. [CrossRef]

40. Rioux, L.-E.; Turgeon, S.L.; Beaulieu, M. Effect of season on the composition of bioactive polysaccharides from the brown seaweed Saccharina longicruris. Phytochemistry 2009, 70, 1069-1075. [CrossRef] [PubMed]

41. Yaich, H.; Garna, H.; Besbes, S.; Paquot, M.; Blecker, C.; Attia, H. Chemical composition and functional properties of Ulva lactuca seaweed collected in Tunisia. Food Chem. 2011, 128, 895-901. [CrossRef]

42. Yu-Qing, T.; Mahmood, K.; Shehzadi, R.; Ashraf, M.F. Ulva lactuca and its polysaccharides: Food and biomedical aspects. J. Biol. Agric. Healthc. 2016, 6, 140-151.

43. Wu, S.-C.; Wen, T.-N.; Pan, C.-L. Algal-oligosaccharide-lysates prepared by two bacterial agarases stepwise hydrolyzed and their anti-oxidative properties. Fish. Sci. 2005, 71, 1149-1159. [CrossRef]

44. Hammed, A.M.; Jaswir, I.; Amid, A.; Alam, Z.; Asiyanbi-H, T.T.; Ramli, N. Enzymatic hydrolysis of plants and algae for extraction of bioactive compounds. Food Rev. Int. 2013, 29, 352-370. [CrossRef]

45. Coste, O.; Malta, E.-j.; López, J.C.; Fernández-Díaz, C. Production of sulfated oligosaccharides from the seaweed Ulva sp. using a new ulvan-degrading enzymatic bacterial crude extract. Algal Res. 2015, 10, 224-231. [CrossRef]

46. He, C.; Muramatsu, H.; Kato, S.-i.; Ohnishi, K. Characterization of an Alteromonas long-type ulvan lyase involved in the degradation of ulvan extracted from Ulva ohnoi. Biosci. Biotechnol. Biochem. 2017, 81, 2145-2151. [CrossRef]

47. Patel, S.; Goyal, A. Functional oligosaccharides: Production, properties and applications. World J. Microbiol. Biotechnol. 2011, 27, 1119-1128. [CrossRef]

48. Lan, K.; Xu, Y.; Kim, H.; Ham, C.; Kelley, S.S.; Park, S. Techno-economic analysis of producing xylo-oligosaccharides and cellulose microfibers from lignocellulosic biomass. Bioresour. Technol. 2021, 340, 125726. [CrossRef]

49. Costa, C.; Alves, A.; Pinto, P.R.; Sousa, R.A.; da Silva, E.A.B.; Reis, R.L.; Rodrigues, A.E. Characterization of ulvan extracts to assess the effect of different steps in the extraction procedure. Carbohydr. Polym. 2012, 88, 537-546. [CrossRef]

50. Glasson, C.R.; Sims, I.M.; Carnachan, S.M.; de Nys, R.; Magnusson, M. A cascading biorefinery process targeting sulfated polysaccharides (ulvan) from Ulva ohnoi. Algal Res. 2017, 27, 383-391. [CrossRef]

51. Fleita, D.; El-Sayed, M.; Rifaat, D. Evaluation of the antioxidant activity of enzymatically-hydrolyzed sulfated polysaccharides extracted from red algae; Pterocladia capillacea. LWT-Food Sci. Technol. 2015, 63, 1236-1244. [CrossRef]

52. Abd-Rahim, F.; Wasoh, H.; Zakaria, M.R.; Ariff, A.; Kapri, R.; Ramli, N.; Siew-Ling, L. Production of high yield sugars from Kappaphycus alvarezii using combined methods of chemical and enzymatic hydrolysis. Food Hydrocoll. 2014, 42, 309-315. [CrossRef]

53. Chen, M.; Zhao, J.; Xia, L. Enzymatic hydrolysis of maize straw polysaccharides for the production of reducing sugars. Carbohydr. Polym. 2008, 71, 411-415. [CrossRef]

54. Charoensiddhi, S.; Conlon, M.A.; Franco, C.M.; Zhang, W. The development of seaweed-derived bioactive compounds for use as prebiotics and nutraceuticals using enzyme technologies. Trends Food Sci. Tech. 2017, 70, 20-33. [CrossRef]

55. Foran, E.; Buravenkov, V.; Kopel, M.; Mizrahi, N.; Shoshani, S.; Helbert, W.; Banin, E. Functional characterization of a novel "ulvan utilization loci" found in Alteromonas sp. LOR genome. Algal Res. 2017, 25, 39-46. [CrossRef]

56. Zou, P.; Yang, X.; Wang, J.; Li, Y.; Yu, H.; Zhang, Y.; Liu, G. Advances in characterisation and biological activities of chitosan and chitosan oligosaccharides. Food Chem. 2016, 190, 1174-1181. [CrossRef]

57. Jayapal, N.; Samanta, A.; Kolte, A.P.; Senani, S.; Sridhar, M.; Suresh, K.; Sampath, K. Value addition to sugarcane bagasse: Xylan extraction and its process optimization for xylooligosaccharides production. Ind. Crops Prod. 2013, 42, 14-24. [CrossRef]

58. Schwanninger, M.; Rodrigues, J.; Pereira, H.; Hinterstoisser, B. Effects of short-time vibratory ball milling on the shape of FT-IR spectra of wood and cellulose. Vib. Spectrosc. 2004, 36, 23-40. [CrossRef]

59. Murphy, V.; Hughes, H.; McLoughlin, P. Comparative study of chromium biosorption by red, green and brown seaweed biomass. Chemosphere 2008, 70, 1128-1134. [CrossRef] [PubMed]

60. Robic, A.; Bertrand, D.; Sassi, J.-F.; Lerat, Y.; Lahaye, M. Determination of the chemical composition of ulvan, a cell wall polysaccharide from Ulva spp.(Ulvales, Chlorophyta) by FT-IR and chemometrics. J. Appl. Phycol. 2009, 21, 451-456. [CrossRef]

61. Percival, E. The polysaccharides of green, red and brown seaweeds: Their basic structure, biosynthesis and function. Br. Phycol. J. 1979, 14, 103-117. [CrossRef]

62. Pereira, L.; Amado, A.M.; Critchley, A.T.; Van de Velde, F.; Ribeiro-Claro, P.J. Identification of selected seaweed polysaccharides (phycocolloids) by vibrational spectroscopy (FTIR-ATR and FT-Raman). Food Hydrocoll. 2009, 23, 1903-1909. [CrossRef]

63. Oliveira, R.C.; Hammer, P.; Guibal, E.; Taulemesse, J.-M.; Garcia Jr, O. Characterization of metal-biomass interactions in the lanthanum (III) biosorption on Sargassum sp. using SEM/EDX, FTIR, and XPS: Preliminary studies. Chem. Eng. J. 2014, 239, 381-391. [CrossRef]

64. Molyneux, P. The use of the stable free radical diphenylpicrylhydrazyl (DPPH) for estimating antioxidant activity. Songklanakarin, J. Sci. Technol. 2004, 26, 211-219.

65. Cheng, J.; Zhang, W.; Zhang, X.; Han, F.; Li, X.; He, X.; Li, Q.; Chen, J. Effect of angiotensin-converting enzyme inhibitors and angiotensin II receptor blockers on all-cause mortality, cardiovascular deaths, and cardiovascular events in patients with diabetes mellitus: A meta-analysis. JAMA Intern. Med. 2014, 174, 773-785. [CrossRef] 
66. Li, J.; Liu, Y.; Fan, L.; Ai, L.; Shan, L. Antioxidant activities of polysaccharides from the fruiting bodies of Zizyphus Jujuba cv. Jinsixiaozao. Carbohydr. Polym. 2011, 84, 390-394. [CrossRef]

67. Liang, N.; Kitts, D.D. Antioxidant property of coffee components: Assessment of methods that define mechanisms of action. Molecules 2014, 19, 19180-19208. [CrossRef]

68. Wang, P.; Jiang, X.; Jiang, Y.; Hu, X.; Mou, H.; Li, M.; Guan, H. In vitro antioxidative activities of three marine oligosaccharides. Nat. Prod. Res. 2007, 21, 646-654. [CrossRef]

69. Costa, L.; Fidelis, G.; Cordeiro, S.L.; Oliveira, R.; Sabry, D.d.A.; Câmara, R.; Nobre, L.; Costa, M.; Almeida-Lima, J.; Farias, E. Biological activities of sulfated polysaccharides from tropical seaweeds. Biomed. Pharmacother. 2010, 64, 21-28. [CrossRef]

70. Ferreira, I.C.; Baptista, P.; Vilas-Boas, M.; Barros, L. Free-radical scavenging capacity and reducing power of wild edible mushrooms from northeast Portugal: Individual cap and stipe activity. Food Chem. 2007, 100, 1511-1516. [CrossRef]

71. Dong, J.; Xu, X.; Liang, Y.; Head, R.; Bennett, L. Inhibition of angiotensin converting enzyme (ACE) activity by polyphenols from tea (Camellia sinensis) and links to processing method. Food Funct. 2011, 2, 310-319. [CrossRef] [PubMed]

72. Krichen, F.; Karaoud, W.; Sayari, N.; Sila, A.; Kallel, F.; Ellouz-Chaabouni, S.; Bougatef, A. Sulfated polysaccharides from Tunisian fish skins: Antioxidant, DNA damage protective effect and antihypertensive activities. J. Polym. Environ. 2016, 24, 166-175. [CrossRef]

73. Admassu, H.; Gasmalla, M.A.A.; Yang, R.; Zhao, W. Bioactive peptides derived from seaweed protein and their health benefits: Antihypertensive, antioxidant, and antidiabetic properties. J. Food Sci. 2018, 83, 6-16. [CrossRef]

74. Cian, R.E.; Garzón, A.G.; Ancona, D.B.; Guerrero, L.C.; Drago, S.R. Hydrolyzates from Pyropia columbina seaweed have antiplatelet aggregation, antioxidant and ACE I inhibitory peptides which maintain bioactivity after simulated gastrointestinal digestion. LWT-Food Sci. Technol. 2015, 64, 881-888. [CrossRef]

75. Qu, W.; Ma, H.; Li, W.; Pan, Z.; Owusu, J.; Venkitasamy, C. Performance of coupled enzymatic hydrolysis and membrane separation bioreactor for antihypertensive peptides production from Porphyra yezoensis protein. Process. Biochem. 2015, 50, 245-252. [CrossRef]

76. Ikeda, K.; Kitamura, A.; Machida, H.; Watanabe, M.; Negishi, H.; Hiraoka, J.; Nakano, T. Effect of Undaria pinnatifida (Wakame) on the development of cerebrovascular diseases in stroke-prone spontaneously hypertensive rats. Clin. Exp. Pharmacol. Physiol. 2003, 30, 44-48. [CrossRef]

77. Jiménez-Escrig, A.; Gómez-Ordóñez, E.; Rupérez, P. Chapter 26-Seaweed as a source of novel nutraceuticals: Sulfated polysaccharides and peptides. In Advances in Food and Nutrition Research; Kim, S.-K., Ed.; Academic Press: Cambridge, MA, USA, 2011; Volume 64, pp. 325-337. [CrossRef]

78. Wijesekara, I.; Kim, S.-K. Angiotensin-I-converting enzyme (ACE) inhibitors from marine resources: Prospects in the pharmaceutical industry. Mar. Drugs 2010, 8, 1080-1093. [CrossRef] [PubMed]

79. Chaki, T.; Kajimoto, N.; Ogawa, H.; Baba, T.; Hiura, N. Metabolism and calcium antagonism of sodium alginate oligosaccharides. Biosci. Biotechnol. Biochem. 2007, 71, 1819-1825. [CrossRef] [PubMed]

80. Endringer, D.; Oliveira, O.; Braga, F. In vitro and in silico inhibition of angiotensin-converting enzyme by carbohydrates and cyclitols. Chem. Pap. 2014, 68, 37-45. [CrossRef]

81. Song, Q.; Li, T.; Xue, W.; Li, N.; Chen, L.; Dai, S.; Zhu, Z. Preparation, structure analysis and ACE inhibitory activity of konjac oligosaccharide. Ind. Crop. Prod. 2018, 124, 812-821. [CrossRef] 